\title{
Sağ Sinüs Valsalva'dan Çıkan Sol Ana Koroner Arter Anomalisi
} Anomaly of the Left Main Coronary Artery Arising from the Right Sinus of Valsalva

\section{Şeref ALPSOY', Aydın AKYÜZ', Dursun Çayan AKKOYUN', Ramazan UYGUR², Selami GÜRKAN}

\author{
${ }^{1}$ Namık Kemal Üniversitesi Tıp Fakültesi,Kardiyoloji AD, Tekirdağ \\ ${ }^{2}$ Namık Kemal Üniversitesi Tıp Fakültesi, Anatomi AD, Tekirdağ \\ ${ }^{3}$ Namık Kemal Üniversitesi Tıp Fakültesi,Kalp ve Damar Cerrahisi AD, Tekirdağ
}

\begin{abstract}
öz
Sağ sinüs Valsalva'dan çıkan sol ana koroner arter anomalisi, oldukça nadir görülen bir konjenital anomalidir. Tamamen semptomsuz olabildiği gibi, egzersiz ile oluşan göğüs ağrısı ve bayılma, miyokart enfarktüsü ve ani ölüm gibi ciddi klinik tablolar ile de ortaya çıkabilir. Yazımızda, sol ana koroner arterin sağ sinüs Valsalva'dan çıkış anomalisi sunulmaktadır.
\end{abstract}

Anahtar Kelimeler: Sol ana koroner arter, anomali, anjiyografi

\section{ABSTRACT}

The anomalous of left main coronary artery arising from the right sinus of Valsalva is a very rare congenital anomaly. It can be completely asymptomatic or it may occur with serious clinical presentation such as angina pectoris and syncope associated with exercise, myocardial infarction, and sudden death. In this report we presented anomalous origin of the left main coronary artery from the right sinus of Valsalva.

Keywords: Left main coronary artery, anomaly, angiog- 


\section{Giriş̧}

Koroner arter anomalileri nadir görülürler ve genel nüfustaki oranları yaklaşık \%1'dir (1). Koroner arter anomalilerinin çoğu, çocukluk döneminde sessizdirler. Çoğunlukla koroner anjiyografide (KAG) veya otopsi sırasında rastlantısal olarak tespit edilirler. Bazen anomaliler belirti verebilir ve cerrahi tedavi gerektirebilirler. En sık görülen koroner arter anomalileri, koroner arterlerin sinüs Valsalva dışında aortanın başka bir yerinden veya pulmoner arterden çıktığı çıkış anomalileridir (2). Sol ana koroner arterin (SAKA) sağ sinüs Valsalva'dan çıkış anomalisi, nadir olarak görülür. Bu anomali tamamen sessiz seyredebildiği gibi, ilk klinik görünüm ani ölüm de olabilmektedir (3).

Yazımızda, yaşlı bir hastanın rutin koroner anjiyografisi sırasında rastlantısal olarak saptanan, sağ sinüs Valsalva'dan çıkan sol ana koroner arter anomalisi sunulmaktadır.

\section{OLGU SUNUMU}

Bir dış merkezin koroner yoğun bakım ünitesinde, çarpıntı, nefes darlığı ve halsizlik şikayetleri nedeniyle kalp yetersizliği tanısı konularak takip edilmekte olan yetmiş iki yaşındaki kadın hasta, ventriküler taşikardi, hemodinamik bozukluk ve senkop geliştiği için iskemi araştırılması amacıyla hastanemizin kardiyoloji kliniğine sevk edildi. Hasta 10 yıldır hipertansiyon nedeniyle enalapril 20 mg/gün almaktaydı. Fizik muayenede arteriyel kan basıncı 90/40 mmHg, nabız 115 atım/ dk olup ritmikti ve üfürüm yoktu. Hasta soğuk, soluk, terli ve konfüze idi. Elektrokardiyografide sol dal bloğu vardı (Şekil 1). Hemoglobin, açlık

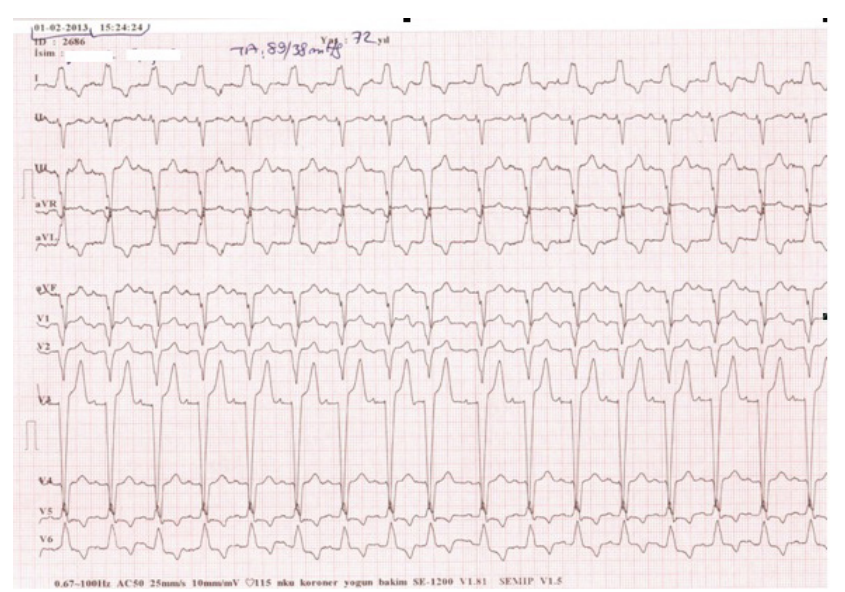

Şekil 1: Hastanın 12 derivasyonlu EKG'sinde sol dal bloğu ve sinüs taşikardisi görülmektedir. kan şekeri, serum lipit değerleri normal, lökosit $(15000 / \mathrm{mm} 3)$ ve troponin değerleri $(0,153 \mathrm{ng} /$ $\mathrm{ml}$ ) hafif yüksekti. Ekokardiyografide interventriküler septum (IVS) paradoks hareketli ve hafif hipertrofikti. İki boyutlu ekokardiyografik incelemede, global sol ventrikül sistolik fonksiyon bozukluğu saptandı. IVS paradoksal hareketi nedeniyle ekokardiyografide sol ventrikül ejeksiyon fraksiyonu (SVEF) tam belirlenemedi. Akut koroner sendroma bağlı kardiyojenik preşok ön tanısı ile acil şartlarda KAG yapılmasına karar verildi ve işlem gerçekleştirildi.

KAG'de sol sinüs Valsalva'dan koroner arter çıkmadığı, SAKA ve sağ koroner arterin ayrı ostiyumlarla sağ sinüs Valsalva'dan çıktıkları görüldü (Şekil 2). SAKA'nın, pulmoner arterin önünden geçerek sol ön inen koroner arter ve sirkumfleks dallarına ayrıldığı tespit edildi (Şekil 3). Koroner arterlerde darlık oluşturan aterosklerotik lezyon saptanmadı (Şekil 4). Sol ventrikülografide SVEF \%35-40 olarak ölçüldü.

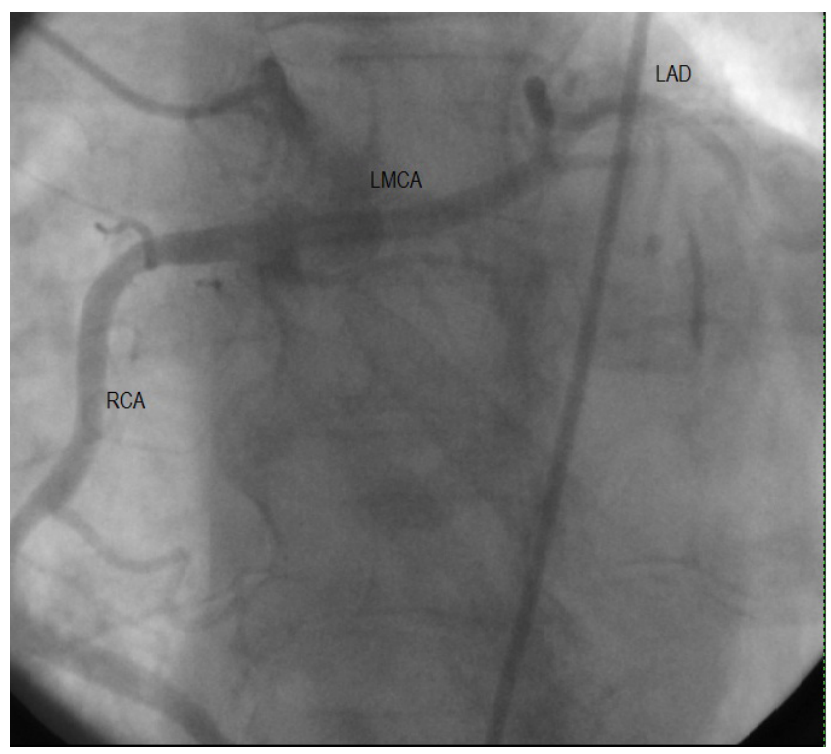

Şekil 2: Koroner anjiyografide sağ koroner ve sol ana koroner arterlerin sağ sinüs Valsalva'dan çıktığı görülmektedir. RCA = Sağ koroner arter, LMCA = Sol ana koroner arter, LAD $=$ Sol ön inen koroner arter

Hastada koroner arter anomalisine bağlı miyokart iskemisi varlığını araştırmak için miyokart perfüzyon sintigrafisi planlandı, ancak bir gün sonra akut böbrek ve karaciğer yetersizliği bulguları görülen hastada solunum yetersizliği de klinik tabloya eklendi. Yoğun girişimlere cevap alınamayan hasta 3. gün eks oldu. 


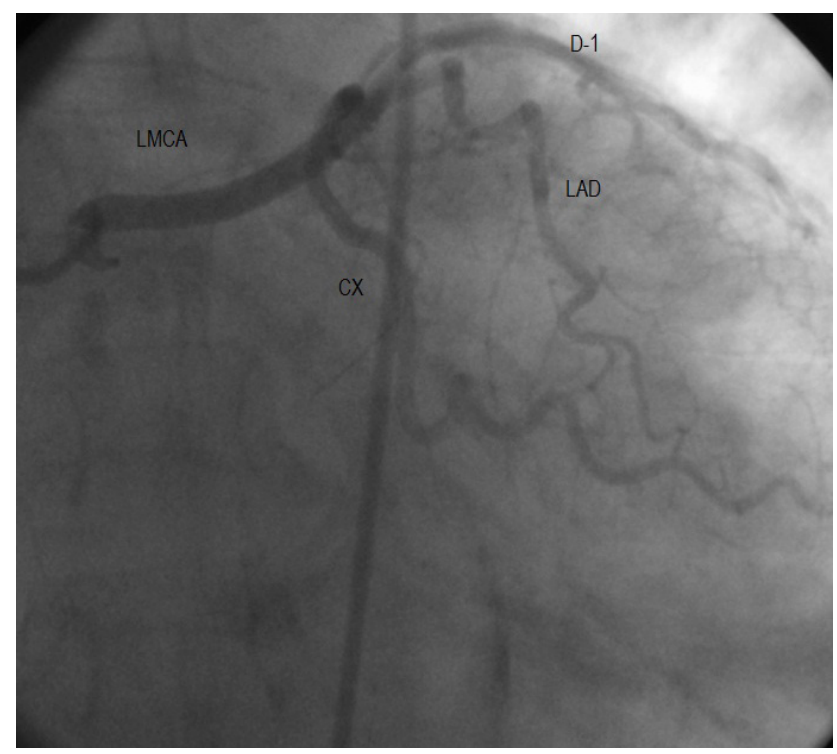

Şekil 3: Postero-anteriyor kaudal pozisyonda, uzun sol ana koroner arterin sağ sinüs Valsalva'dan ayrı bir ostiyum ile çıktıktan sonra pulmoner arterin önünden geçerek sol inen arter ve sirkumfleks artere ayrıldığı görülmektedir. $\mathrm{RCA}=$ Sağ koroner arter, $\mathrm{LMCA}=$ Sol ana koroner arter, $\mathrm{LAD}=$ Sol ön inen koroner arter, $\mathrm{CX}=$ Sirkümfleks koroner arter, $\mathrm{D}-\mathrm{I}=1$. diyagonal koroner arter

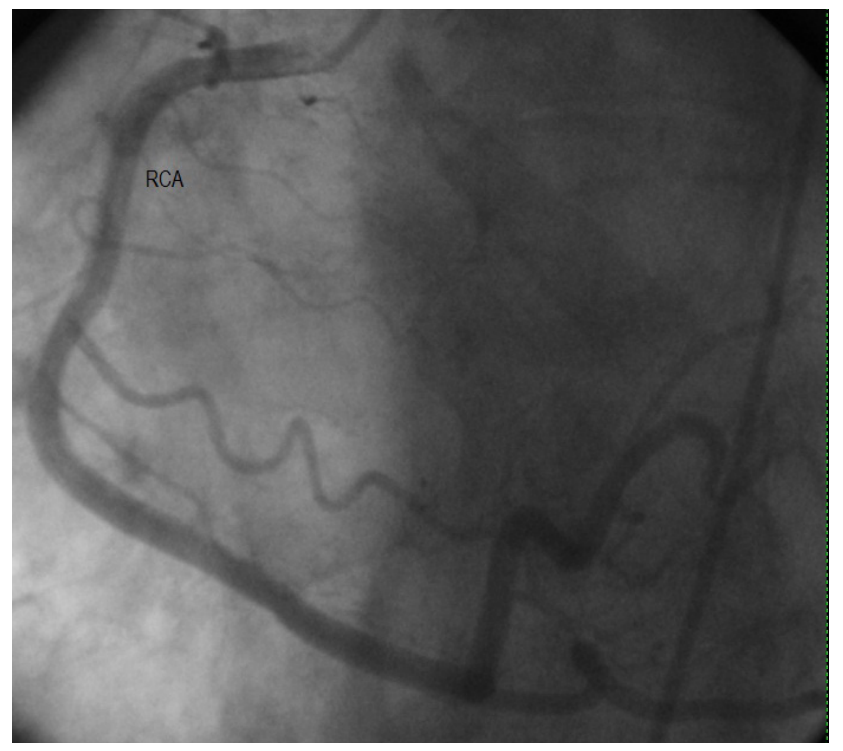

Şekil 4: Sağ koroner arterin sol sinüs Valsalva'dan ayrı ostiyumdan çıktıktan sonra normal seyri görülmektedir.

\section{TARTIŞMA}

Koroner arter anomalileri KAG bulgularına göre \%1,3-5,6 olarak bildirilmektedir $(2,4)$. Bunların \%87'si çıkış ve dağılım anomalisi, \%13'ü koroner fistüllerdir. Çoğu koroner arter anomalisi sessizdir ve komplikasyona yol açmaz (\%80'i iyi huylu). Genellikle kateterizasyon sırasında rastlantısal olarak tespit edilirler.

SAKA'nın sağ sinüs Valsalva'dan çıkış anomalisi $\% 0,017-0,150$ oranında bildirilmiş olup, potan- siyel olarak ciddi anomaliler grubuna girer $(2,4)$. Biküspit aort, büyük damarların transpozisyonu ve koroner arteriyovenöz fistül gibi diğer kardiyak anomaliler de tabloya eşlik edebilirler (5).

SAKA'nın sağ sinüs Valsalva'dan çıkış anomalisi, SAKA'nın aorta ve pulmoner arterle ilişkisine göre beş anatomik alt sınıfa ayrılmaktadır. İlkinde SAKA aortanın arkasında seyreder ve posteriyor tip olarak adlandırılır. İkincisi anteriyor tiptir ki burada SAKA pulmoner arterin önünde seyreder. En sık rastlanan üçüncü tip SAKA'nın interventriküler septum içinde seyrettiği septal tiptir. SAKA'nın, aorta ve pulmoner arter arasından geçtiği tip, aynı zamanda en tehlikeli şekil olan dördüncü tiptir. Bu tipte, koroner ateroskleroz yokluğunda anjina pektoris, senkop, miyokart enfarktüsü, ventriküler taşikardi, kardiyak arrest ve ani ölüm görülebilir. Belirtiler özellikle genç bireylerde, fiziksel egzersiz sırasında oluşur. Egzersiz sonucunda aortada genişleme olduğu, bunun da SAKA'nın akut açılı yarık benzeri orifisinde kapanmaya yol açtığı kabul edilmektedir. Kombine tip olarak isimlendirilen 5. tipte ise anteriyor veya posteriyor tipler septal tip ile beraber bulunur. Anteriyor, posteriyor ve septal olarak adlandırılan ilk üç tip genelde iyi seyirlidir, ancak anjina pektoris, egzersiz ile ilişkili senkop ve miyokart enfarktüsü gelişen vakalar bildirilmiştir (2). SAKA'nın sağdan çıkış anomalisi için belirli bir tedavi stratejisi yoktur. Anormal SAKA seyri ve birlikte koroner arter hastalığı bulunması tedavi stratejisinin belirlenmesinde rol oynar (6). Aorta ve pulmoner arter arasından seyirli tip 4 olgularda cerrahi tedavi gereklidir.

Bizim olgumuzda SAKA, pulmoner arterin önünden seyretmekteydi (tip 2) ve bu durum genel bir yaklaşımla selim seyirli oluşa işaret etmekteydi. Miyokart perfüzyon sintigrafisi yapamadığımız hastamızda anteriyor tip SAKA'nın iskemiye sebep olup olmadığını kesin olarak saptayamadık. Olgumuz yetmiş iki yaşına kadar ani kardiyak ölüm oluşmaksızın asemptomatik kalmıştı. İlave doğumsal kalp hastalığı da yoktu. Hastamızdaki çoklu organ yetersizliği bulguları şok kliniği ile ilintilendirilebilir (böbrekte ve belki miyokartta ilave radyoopak etkisi?) ancak şok kliniğinin etiyolojisi net olarak anlaşılamadı. 
Sonuç olarak, SAKA'nın sağ sinüs Valsalva'dan çıkış anomalisi nadir rastlanan ancak tipine göre ciddi klinik sonuçlara yol açabilecek bir durumdur. Hastalar, olgumuzdaki gibi uzun yıllar asemptomatik kalabilirler. Ancak, özellikle gençlerde, eforla ortaya çıkan göğüs ağrısı ve senkop gibi durumlarda, mutlaka hatırlanmaları ve gerekli görülürse KAG ile durumun aydınlatılmaya çalışılması (özellikle 4. tipin saptanması durumunda cerrahi gereklilik), ani ölüm riski taşımaları nedeniyle önemlidir.

\section{KAYNAKLAR}

1. Angelini P, Velasco JA, Flamm S. Coronary anomalies: incidence, pathophysiology, and clinical relevance. Circulation 2002;105(20):2449-54.

2. Yamanaka O, Hobbs RE. Coronary artery anomalies in 126,595 patients undergoing coronary angiography. Cathet Cardiovasc Diagn 1990;21(1):28-40.

3. Basso C, Maron BJ, Corrado D, Thiene G. Clinical profile of congenital coronary artery anomalies with origin from the wrong aortic sinus leading to sudden death in young competitive athletes. J Am Coll Cardiol 2000;35(6):1493501.

4. Angelini $P$ (Editör). Coronary Artery Anomalies: $A$ Comprehensive Approach. In: Angelini P, Villason S, Chan AV, Diez JG. Normal and anomalous coronary arteries in humans. Philadelphia: Lippincott Williams\&Wilkins, 1999,27-150.

5. Sharbaugh AH, White RS. Single coronary artery: Analysis of the anatomic variation, clinical importance and report of five cases. JAMA 1974;230(2):243-6.

6. Braun MU, Stolte D, Rauwolf T, Strasser RH. Single coronary artery with anomalous origin from the right sinus Valsalva. Clin Res Cardiol 2006;95(2):119-21. 